\title{
Commentary
}

\section{And So It Begins: Trade and Sustainable Development Recommendations by a Panel of Experts under a European Union Free Trade Agreement} By Aleydis Nissen, Postdoc Researcher, Institutions for Conflict Resolution Research Group, Leiden University, the Netherlands; VUB (FWo postdoc grant 74910); ULB (F.R.S.-FNRS chargé de recherches grant FC 38129)

\section{Introduction*}

An ad hoc Panel of Experts has determined for the first time that a free trade partner of the European Union violated sustainable development obligations under the new generation of free trade agreements (FTAs). ${ }^{1}$ The Republic of Korea (Korea) was the EU's first trading partner to ratify such an agreement. ${ }^{2}$ After a European Commission non-paper in 2018 promised "more assertive" use of the soft dispute mechanism for "trade and sustainable development" (TSD) issues in free trade agreements, the EU filed formal proceedings against

* I thank Paul van der Heijden and Stefania Marassi. For reasons of consistency, this article places the Korean family name after the given name in the footnotes and the discussion of the composition of the Panel of Experts.

1 Panel of Experts, "Proceeding Constituted under Article 13.15 of the EU-Korea Free Trade Agreement," 2021, https://trade.ec.europa.eu/doclib/docs/2021/january/tradoc_159358.pdf (hereafter: Panel of Experts, Report).

2 Free Trade Agreement between the European Union and its Member States, of the one part, and the Republic of Korea, of the other (signed 6 October 2010, entered into force 13 December 2014) L127 6 (EU-Korea FTA). 
Korea. ${ }^{3}$ The Panel's report is a milestone decision that will likely serve as a precedent for future ad hoc panels.

The Panel-consisting of Laurence Boisson de Chazournes, Jaemin Lee, and Jill Murray as chairperson-had considered two EU claims involving TSD issues in the EU-Korea FTA. ${ }^{4}$ The claims related to the first and the last sentences of Article 13.4.3 of that agreement. The first sentence explains that the parties commit to respecting, promoting, and realizing the principles concerning the fundamental labor rights in their laws and practices in accordance with the obligations deriving from ILO membership. The EU asserted that Korea had violated this provision. Articles 2(1), 2(4)(d), 23(1) and 12(1)-(3), in conjunction with Articles 2(4) and 10 of Korea's Trade Union and Labor Relations Adjustment Act (TULRAA) of 1997, the EU complained, would not be in accordance with freedom of association. ${ }^{5}$ The last sentence of Article 13.4.3 of the EU-Korea FTA stipulates that the parties are required to "make continued and sustained efforts towards ratifying the fundamental ILO Conventions." The EU alleged that such efforts had not been made regarding four relevant fundamental conventions: Nos. 29, 97, 98, and 105 .

\section{Panel Determinations}

The Panel first determined that it had jurisdiction. The Panel's findings on the relationship between sustainable development and trade are the most interesting part of these determinations. The EU had in its request gone to great lengths to not directly refer to labor issues in the export industries in its Panel Request. ${ }^{6}$ It made sense for Korea in its defense to try to weaponize the EU's nonconfrontational approach. Korea asserted that the issues at hand were not related to trade. It noted that it did not believe that "alleged difficulties experienced by, for example, chauffeur service drivers will affect trade

3 European Commission (EC), "Non-paper of the Commission Services: Feedback and Way Forward on Improving the Implementation and Enforcement of Trade and Sustainable Development Chapters in EU Free Trade Agreements," 2018, 8-9, https://trade.ec.europa.eu/ doclib/docs/2018/february/tradoc_156618.pdf.

4 Panel of Experts, Report no. 100-4, 261 and 264. Rieu Kim was the secretary to the Panel.

5 EU, "Panel of Experts Proceedings under Article 13.15 of the EU - Korea FTA. First Written Submission," 2020, https://trade.ec.europa.eu/doclib/docs/2020/january/tradoc_158585.pdf.

6 Aleydis Nissen, "Towards 'More Assertive Enforcement' of Labour Obligations in EU FTAs" (working paper, 2021). 
between Korea and the European Union..7 It argued that the EU's request fell outside the Panel's jurisdiction because Article 13.2.1 of the EU-Korea FTA limited Chapter 13 to trade-related aspects: "Except as otherwise provided ..., this Chapter applies to measures adopted or maintained by the Parties affecting trade-related aspects of labour and environmental issues." The Panel, disagreeing, determined that "[i]t is not appropriate, or even possible, to apply the limited scope bounded by 'trade-related labour' to the terms of Article 13.4.3." The Panel interpreted this article as an exception that Article 13.2.1 allows to exist and went even further, claiming that the issues at hand were "inherently related to trade." It did not find the EU's Request protectionist per se, stating as unfounded any fears that core labor standards might influence Korea's competitive position. In this regard, the Panel referred to an empirical study by the Organisation for Economic Cooperation and Development, the findings of which the ILO had confirmed in more recent research. ${ }^{10}$

The Panel confirmed that the two EU claims refer to legally binding obligations set out in the first and the last sentences of Article 13.4.3.1

The Panel first considered the EU's complaints regarding the first sentence of Article 13.4.3. The Panel's interpretation of these substantive issues was relatively straightforward, in that the Panel decided to give "appropriate weight ... to the general principles set out in the [ILO Committee on Freedom of Association]'s Compilation of Decisions." ${ }^{12}$ It noted that an interpretation in good faith -in line with Article 31 of the Vienna Convention on the Law of Treaties (1969) —warrants such interpretation..$^{13}$ These principles had been recognized as "persuasive and authoritative" by various national, regional, and international courts and supervisory bodies. ${ }^{14}$

The Panel was concerned that Article 2(1) TULRAA defines a worker as a person who lives on wages, a salary, or another equivalent form of income earned in pursuit of any job. This definition excludes dismissed, self-employed, and unemployed persons. That it does was, among other things, problematic because Article 2(4)(d) TULRAA determines that an organization cannot be trade.ec.europa. eu/doclib/docs/2020/november/tradoc_159077.pdf (hereafter: Panel of Experts, Hearing report) 6.

8 Panel of Experts, Report, 68.

9 Ibid., 63 .

10 Ibid., $85-89$.

$11 \quad$ Ibid., 141 and 277.

12 Ibid., 115 .

13 Ibid., 116 .

14 Ibid., 117. 
considered a trade union if nonworkers have joined. The Panel held that the freedom of association not only of self-employed, dismissed, and unemployed workers is impaired, but also of every other member of an enterprise union or non-enterprise union that risks decertification by permitting such workers to become and stay members. ${ }^{15}$ The Panel also ruled against Article 23(1) TULRAA that union officials must be selected from among members of the union, thus ensuring that the members of enterprise and non-enterprise unions may elect officials in full freedom. ${ }^{16}$

The Panel determined that Korea violated the first sentence of Article 13.4.3 of the EU-Korea FTA because these TULRAA provisions violate both freedom of association and effective recognition of collective bargaining. ${ }^{17}$

The Panel rejected the EU's claim regarding Article 12(1)-(3) in conjunction with Articles 2(4) and 10 TULRAA. These articles contain a certification procedure for the establishment of trade unions. ${ }^{18}$ According to the EU, this procedure impedes the right to join trade unions without previous authorization. The Panel, however, referred to the Korean Constitutional Court, which had determined in 2011 that this procedure was constitutional..$^{19}$ In so doing, the Panel evaded commenting on a sensitive issue, the relation between the Korean constitution and international law obligations, ${ }^{20}$ saying that it was unable to conclude that Article 12(3) TULRAA violates the final sentence of Article 13.4.3 of the EU-Korea FTA in practice. ${ }^{21}$

Further, the Panel considered whether Korea had violated the last sentence of Article 13.4.3 EU-Korea FTA, which requires continued and sustained efforts of the Parties towards ratifying the fundamental ILO Conventions Nos. 29, 97, 98 , and 105 . According to the EU, Korea did not take any significant steps during the Lee Myun-bak and Park Geun-hye administrations. It emphasized that this span of time amounted to two-thirds of the nine years the relevant provision

15 Ibid., 196 and 206-209.

16 Ibid., 227.

17 Ibid., 104, 16o-1, 216-220.

18 Panel of Experts, Report, 257. See also Hyuk Kwon, "Workers Rights," in The Evolution of Korean Industrial and Employment Relations, edited by Young-Myon Lee and Bruce E. Kaufman (Cheltenham, UK: Elgar, 2018).

19 Panel of Experts, Report, 254.

20 Art 6(1) Constitution 1948 (KR); Nohyoung Park, "Application of International Law in Korean Courts," Asia Law Review 1 (2004): 23; Jongcheol Kim, "Courts in the Republic of Korea: Featuring a Built-In Authoritarian Legacy of Centralization and Bureaucratization," in Asian Courts in Context edited by Jiunn-rong Yeh and Wen-Chen Chang (Cambridge: Cambridge University Press, 2014): 113.

Panel of Experts, Report, 256. 
has been in application. ${ }^{22}$ The Moon Jae-in administration announced its plan to submit the bills for ratification of ILO Conventions Nos. 29, 97, and 98 to the National Assembly in May 2019. The bills were submitted in October 2019. In regard to Convention 105, Korea held that domestic changes in the penal system require longer discussions. The Panel determined that Korea's ratification efforts for all four core labor rights conventions were "tangible" and did not fall below the legal standard stipulated in Article 13.4.3. ${ }^{23}$ It noted that Article 13.4.3 did not require that ratification efforts should take place "without interruption." ${ }^{24}$ or set a target date or milestone for the ratification process. ${ }^{25}$ The Panel, like the UN Committee on Economic, Social and Cultural Rights a year earlier, said that it remained mindful that Korea had not committed to a specific time frame. ${ }^{26}$ Steve Peers warned that the Panel's interpretation might send a message to "non-EU countries" that a delay of nearly a decade in ratifying the fundamental ILo Conventions is acceptable. ${ }^{27}$ But I think that it is an important reminder for the European Commission that it needs to reinforce the promise-made in the 2018 non-paper-on delivering "early" ratification results, preferably before free trade agreements are concluded. ${ }^{28}$

\section{Looking Forward}

Korea and the EU now need to make their best efforts to accommodate the Panel recommendations (see Article 13.15.2). The Committee on TSD will monitor progress. Interestingly, the Panel explicitly recommended that this Committee and other specialized bodies under Article 13.12 continue to consult the EU and Korea regarding the certification procedure.

In January 2021, the European Commission published a glowing press release on the value of its cooperation-based approach simultaneously with

\footnotetext{
22 Panel of Experts, Hearing report EU answer to written question 6.

23 Panel of Experts, Report, 287 and 292.

24 Ibid., 270 and 273.

25 Ibid., 276 and 278.

26 Hwangbo Yon 2020, "UN Calls for S. Korea to Ratify Core ILo Conventions" Hankyoreh, 6 January 2020, http://english.hani.co.kr/arti/english_edition/e_international/923345.html.

27 Steve Peers, "Free Trade v Freedom of Association? The EU/South Korea Free Trade Agreement and the Panel Report on the EU Challenge to South Korean Labour Law," EU Law Analysis (blog), 26 January 2021, http://eulawanalysis.blogspot.com/2021/o1/free-tradev-freedom-of-association.html.

28 EC, "Non-paper of the Commission Services," 8-9.
} 
the Panel report. ${ }^{29}$ In April 2021, Korea ratified ILO Conventions Nos. 29, 97, and 98. Sabine Weyand, the EC director general for trade, claimed that this was "enforcement of our \#TSD chapter EU-Korea in practice."30 Korea has been more reluctant to credit the EU. Most notably, during the proceedings in the Panel of Experts, the ratification efforts were said to be unrelated to the dialogue with the EU. ${ }^{31}$

The Panel needs to be commended for clearly and elaborately discussing its interpretations in a sensitive dispute fraught with differences and misunderstandings. It might be a missed opportunity that the report nowhere refers explicitly to the expertise on the issues at hand of Korean scholars, although it cites numerous equally excellent writings by scholars from the EU and the core Anglosphere. In so doing, hegemonic power relations were unnecessarily reenacted. Citations matter, ${ }^{32}$ particularly at the close of a dispute proceeding that needs to bring government and nongovernmental actors of Korea and the EU together. ${ }^{33}$

29 Nissen, "Towards 'More Assertive Enforcement," referring to EC, "Panel of Experts Confirms Republic of Korea is in Breach of Labour Commitments under our Trade Agreement," 2021, https://trade.ec.europa.eu/doclib/press/index.cfm?id=2238.

30 Sabine Weyand, "Enforcement of our \#TSD chapter EU-Korea in Practice," Twitter, 26 February 2021, https://twitter.com/WeyandSabine/status/1365222408454627334.

31 Panel of Experts, Hearing report, 24.

32 Cf Michelle Lazar, "Feminist Critical Analyses," Critical Discourse Studies 4, no. 2 (2007): 155.

33 Cf Axel Marx, Jan Wouters, Woosik Moon, Yeongsep Rhee, and Sunhee Park, "EU-Korea Relations in a Changing World Project: Main Results and Recommendations," Asia Europe Journal 12 (2014): 246-47. 